\title{
PERKEMBANGAN KEPRIBADIAN TOKOH FRIEDRICH MERGEL DALAM NOVELLE DIE JUDENBUCHE KARYA ANNETE VON DRÖSTE HULSHOFF
}

\author{
Isti Haryati \\ Fakultas Bahasa dan Seni, Universitas Negeri Yogyakarta \\ haryati.istihar@gmail.com
}

\begin{abstract}
ABSTRAK
Tujuan penelitian ini adalah mendeskripsikan perkembangan kepribadian tokoh Friedrich Mergel sebagai dampak lingkungan dalam NovelleDie Judenbuche karya Annete von Dröste Hulshoff.Penelitian ini adalah deskriptif kualitatif dengan menggunakan pendekatan psikologis. Hasil penelitian menunjukkan bahwa perkembangan kepribadian Friedrich dipengaruhi oleh tiga hal yaitu seleksi alam, praktik budaya berupa kontrol sosial, dansejarah seseorang atas penguatan (reinforcement) yang diterima. Perkembangan kepribadian Friedrich terbagi dalam beberapa fase kehidupan Friedrich, yakni pada masa kecil Friedrich, saat kematian ayahnya, saat Friedrich diadopsi Simon Semmler, ketika terlibat atas kematian Brandis, saat pembunuhan terhadap Aaron, serta saat Friedrich kembali dan bunuh diri. Dalam keenam fase tersebut, ketiga faktor yangmembentuk kepribadian seseorang, yakni seleksi alam, praktik budaya berupa kontrol sosial, dan penguatan (reinforcement) pada diri Friedrich, saling memberikan pengaruh dan berkaitan satu sama lain.
\end{abstract}

Kata kunci: perkembangan kepribadian, psikologisastra, Novelle Die Judenbuche

\section{CHARACTER PERSONALITYDEVELOPMENTFRIEDRICHMERGEL IN ANNETTEVONDROSTEHULSHOFF'S NOVELLE ENTITLED DIE JUDENBUCHE}

\begin{abstract}
This research aims at describing the personality development of Friedrich Mergel, a character in a novellet entitled Die Judenbuche written by Annete von DrösteHulshoff. This research is a qualitative-descriptive research using psychological approach. The results of the research show that the personality development of the character is influenced by three things namely 1) natural selection, 2) cultural practice in the form of social control, and 3) the personal history of the accepted reinforcement. The development of the personality of Friedrich is divided into some stages, that is, 1) Friedrich's childhood, 2) the time of his father's death, 3) the time he was adopted by Simon Semmler, 4) the time he was involved in Brandis' death, 5) the time when Aaron was murdered, and 6) the time when he came back and committed suicide. Of all the six stages of his life, the three factors creating somebody's personality, which are natural selection, the cultural practice in the form of social control, and the reinforcement toward Friedrich, influence and relate one another.
\end{abstract}

Keywords: personality development, literary psychology, Novelle DieJudenbuche

\section{PENDAHULUAN}

Lingkungan merupakan salah satu kenyataan yang digambarkan oleh pengarang dalam karya sastra. Lingkungan menjadi sebuah setting yang melatarbelakangi sebuah konflik dalam cerita. Secara umum, lingkungan akan mempengaruhi kehidupan masyarakat sekelilingnya. Begitu jugalingkungan yang digambarkan dalam karya sastra biasanya membentuk kepribadian tokoh dalam karya sastra tersebut. Lingkungan yang baik akan membentuk kepribadian baik, demikian juga lingkungan yang 
tidak baik juga akan membentuk kepribadian tokoh yang tidak baik pula.

Penggambaran lingkungan yang begitu detil dan mempengaruhi kepribadian tokohnya tampak dalam sebuah roman dalam sastra Jerman, yakni Novelle die Judenbuche karya Annette von Dröste Hullshof. Novelle ini menceritakan kehidupan masyarakat di sebuah desa B, yakni kota kecil pada abad 18 setelah pecahnya Revolusi Perancis. Dengan detil digambarkan bagaimana kondisi masyarakat di desa $\mathrm{B}$ yang dibingungkan dengan masalah moral sehingga sebuah kejahatan sulit dimaknai sebagai sebuah kejahatan. Lingkungan di desa B digambarkan sangat kacau karena ketidakjelasan patokan moral dalam masyarakat.

Sebagai sebuah karya sastra yang masuk dalam Epoche Biedermeier dalam sejarah Jerman, Novelledi Judenbuche ini dengan detil menggambarkan lingkungan masyarakat desa $\mathrm{B}$ yang membentuk pribadi seorang tokoh bernama Friedrich Mergel. Friedrich Mergel dilahirkan sebagai seorang anak pemilik tanah di desa B. Dalam rumahnya, kekacauan dan kejahatan juga digambarkan dengan jelas. Ayahnya adalah seorang pemabuk yang kemudian ditemukan mati dalam kondisi membeku karena mabuk di sebuah hutan Brederholz. Kematian ayahnya membuat pribadi Friedrich berubah menjadi tertutupsehingga kemudian dia diasuh oleh pamannnya. Lingkungan hidup dalam asuhan pamannya membuat Friedrich membuatnya berubah, dari yang semula tertutup menjadi seorang pemberani dan bahkan ditakuti.

Gambaran lingkungan dalam Novelle die Judenbuche, di mana tidak ada patokan moral yang jelas, membuat masyarakat desa B bingung. Keadilan dan ketidakadilan, kebaikan dan kejahatan menjadi tidak jelas bagi masyarakat karena tidak adanya norma yang mengikat kehidupan warga masyarakat. Demikian juga tentang peristiwa kriminal berupa pembunuhan yang dilakukan oleh Friedrich di akhir Novelle yang tidak ada penyelesaiannya secara pasti. Alamlah akhirnya yang menghukum Friedrich, sehingga meskipun sudah melarikan diri jauh dari desa B, Friedrich akhirnya kembali dan menggantungkan diri di pohon Buche, tempat di mana dulu dia membunuh seorang Yahudi bernama Aron.
Perkembangan kepribadian tokoh Friedrich sebagai dampak lingkungan ini penting untuk diteliti.Fenomena gambaran lingkungan pada Novelledie Judenbuche tersebut, bisa kita jadikan pelajaran bagaimana seharusnya patokan moral itu ditempatkan dalam masyarakat. Lingkungan yang tidak menjunjung tinggi norma dan hukum akan membuat kehidupan kita menjadi kacau seperti yang terjadi pada Novelle tersebut.

Untuk melihat bagaimana gambaran lingkungan (Millieu) dan pengaruhnya terhadap kepribadian tokoh Friedrich Mergel tersebut diperlukan satu teori yakni teori psikologi sastra. Tujuan psikologi sastra adalah memahami aspek kejiwaan yang terkandung dalam karya sastra(Ratna, 2004: 342).

Teori psikologi sastra berawal dari pemikiran bahwa karya sastra mengandung aspekaspek kejiwaan yang sangat kaya (Ratna, 2004: 341). Psikologi sastra bertujuan untuk memahami aspek-aspek kejiwaan yang terkandung dalam sebuah karya. Karena karya sastra memasukkan berbagai aspek kehidupan, khususnya manusia, maka aspek-aspek kemanusiaan inilah yang yang merupakan objek utama karya sastra.

Ada tiga cara yang dapat dilakukan untuk memahami hubungan antara psikologi dan sastra, yaitu : a) memahami unsur-unsur kejiwaan tokoh-tokoh fiksi dalam karya sastra, b) memahami unsur-unsur kejiwaan tokoh-tokoh dalam karya sastra, c) memahami unsur-unsur kejiwaan pembaca. Penelitian ini lebih memfokuskan hal yang kedua, yakni membicarakan unsur-unsur kejiwaan tokoh-tokoh fiksional dalam karya sastra.

Sastra dan psikologi sama-sama membicarakan manusia, bedanya sastra membicarakan manusia yang diciptakan oleh pengarang (mausia imajiner), sedangkan psikologi membicarakan manusia secara riil hidup di alam nyata. Meskipun karakter manusia di dalam karya sastra bersifat imajiner, tetapi di dalam menggambarkan karakter dan jiwanya pengarang menjadikan manusia yang hidup di alam nyata sebagai model dalam penciptaannya. Dengan demikian, dalam menganalisis aspek kejiwaan tokoh-tokoh dalam karya sastra, maka harus didasarkan pada teori dan hukum-hukum 
psikologi yang menjelaskan aspek kejiwaan tersebut (Wiyatmi, 2011: 5).

Dalam penelitian ini digunakan teori psikologi kepribadian. Psikologi kepribadian dirumuskan sebagai psikologi yang membahas kepribadian, artinya yang dipelajari adalah seluruh pribadinya, bukan hanya pikirannya, perasaannya, dan sebagainya, melainkan secara keseluruhannya, sebagai panduan antara jasmani dan rohani (Sujanto, dkk. 2001: 15). Oleh karena itu, di dalam proses pertumbuhannya dipengaruhi oleh faktor dari dalam yang terdiri atas bermacam-macam disposisi yang dibawa sejak lahir dan juga faktor dari lingkungannya yang terdiri atas bermacam-macam hal.

Dalam penelitian ini, yang digunakan adalah psikologi kepribadian menurut Skinner. Menurut Skinner (Feist, 2011: 164), individu adalah organisme yang memperoleh perbendaharaan tingkah lakunya melalui belajar. Manusia akan berkembang berdasarkan stimulus yang diterimanya dari lingkungan sekitarnya. Lingkungan yang buruk akan menghasilkan manusia buruk, lingkungan yang baik akan menghasilkan manusia baik.

Bagi Skinner (via Feist, 201: 184), studi mengenai kepribadian itu ditujukan pada penemuan pola yang khas dari kaitan antara tingkah laku organisme dan berbagai konsekuensi yang diperkuatnya. Menurut Skinner, perilaku manusia dan kepribadian manusia dibentuk dan dipengaruhi oleh tiga kekuatan, yakni (1) seleksi alam, (2) praktik budaya, dan (3) sejarah seseorang atas penguatan yang diterimanya (Feist, 2011: 177).

Dalam seleksi alam, sebagai individu, perilaku manusia ditentukan oleh komposisi genetis dan terutama oleh sejarah pribadi manusia atas penguatan yang diterima. Akan tetapi, sebagai spesies, kepribadian manusia ditentukan oleh faktor-faktor kemampuan bertahan hidup. Perilaku seseorang yang menguatkan akan cenderung diulangi, dan sepanjang tidak menguatkan akan dihindari atau dibuang.

Dari faktor praktik budaya, perilaku seseorang dikontrol oleh faktor-faktor lingkung-an yang dapat ditegakkan oleh masyarakat, orang lain, atau diri sendiri.Saat kontrol sosial terasa berlebihan, manusia dapat menggunakan tiga strategi dasar untuk melawan hal tersebut, yakni menghindar, memberontak dan resisstensi pasif (Skinner via Feist, 2011: 187).

Selain itu, juga sangat penting dalam perkembangan kepribadian manusia adalah penguatan (reinforcement). Penguatan (reinforcement) manusia atas dirinya, memiliki dua efek, yakni memperkuat perilaku dan memberikan penghargaan pada orang tersebut. Penguatan bisa berupa penguatan yang negatif dan positif. Penguatan positif berupa penguatan yang menghasilkan kondisi lingkungan yang bermanfaat, sedangkan penguatan negatif adalah penguatan yang mereduksi atau menghindari kondisi yang merusak.

\section{METODE PENELITIAN}

Penelitian ini adalah penelitian pustaka yang menggunakan teknik deskriptif kualitatif dengan menggunakan pendekatan psikologis. Penelitian ini akan mendeskripsikan perkembangan kepribadian tokoh Friedrich Mergel karena pengaruh lingkungan dalam NovelleDie Judenbuche karya Annete von Dröste Hulshoff.

Pemerolehan data dilakukan dengan dengan tiga cara, yaitu pembacaan survei, pembacaan terfokus. dan pembacaan verifikasi. Pembacaan survei adalah membaca secara global untuk menemukan masalah, pembacaan terfokus adalah menentukan indikator dalam pembacaan survei, dan pembacaan verifikasi adalah pembacaan untuk menemukan data penelitian.

Analisis data dilakukan dengan teknik deskriptif kualitatif. Tahapan-tahapan yang akan dilakukan dalam penelitian ini adalah dengan (1) menganalisis fase perkembangan kepribadian Friedrich dalam Novelledie Judenbuche, (2) menganalisis perkembangan kepribadian tokoh Friedrich Mergel karena pengaruh lingkungan dalam Novelle die Judenbuche. Dari kedua tahapan tersebut akan diperoleh makna Novelle die Judenbuche dilihat dari perkembangan kepribadian tokoh Friedrich Mergel karena pengaruh lingkungan.

\section{HASIL DAN PEMBAHASAN}

Pada bagian ini akan dipaparkan perkembangan kepribadian tokoh utama Freidrich Mergel yang terbagi dalam beberapa fase penting kehidupannya, dan perkembangan ke- 
pribadian tokoh utama Friedrich Mergel karena pengaruh lingkungan.

\section{Perkembangan Kepribadian tokoh Utama Friedrich Mergel}

Kepribadian manusia dibentuk oleh tiga kekuatan, yakni (1) seleksi alam, (2) praktik budaya dan (3) sejarah seseorang atas penguatan (reinforcement) yang diterima (Skinner, via Feist, 2011: 177). Dalam hal ini, ketiga hal tersebut secara garis besar dikatakan sebagai lingkungan.

Tiga kekuatan yang membentuk kepribadian tersebut kemudian muncul dalam beberapa fase kehidupan tokoh Friedrich Mergel. Ketiga hal tersebut berkembang secara bersamaan dalam perkembangan kepribadian Friedrich. Demikian juga strateginya dalam melawan kontrol sosial yang baginya berlebihan. Perkembangan kepribadian Friedrich dalam Novelle Die Judenbuche ini terbagi dalam beberapa fase penting yang dialami oleh Friedrich. Fase-fase yang penting dalam kehidupan Friedrich Mergel, yang berpengaruh terhadap perkembangan kepribadiannya adalah sebagai berikut.

\section{Saat Friedrich Kecil}

Dalam diri Friedrich, pengaruh seleksi alam dalam pembentukan kepribadiannya meliputi beberapa perilaku yang menguatkan yang kemudian muncul secara berulang, dan juga perilaku yang tidak menguatkan yang kemudian dibuang atau dihilangkan. Perkembangan perilaku Friedrich dilihat dari faktor seleksi alam bisa dilihat pada masa kecil Friedrich.

Masa kecil Friedrich begitu menyenangkan karena ayahnya sangat menyayanginya. Masa kecil yang menyenangkan tersebut belum begitu mempengaruhi kepribadiannya, meskipun digambarkan bagaimana ibunya berusaha mendidiknya dengan menanamkan religiusitas. Margreth memang seorang ibu yang mengutamakan agama dan berusaha menanamkan nilai keagamaan ke dalam diri Friedrich. Kutiban berikut menunjukkan bagaimana Margreth berusaha menanamkan nilai agama pada Friedrich."Kind, bete ein wenig - du kannst ja schon das halbe Vaterunser - daß Gott uns bewahre vor Wasser- und Feuersnot" (Hullshof, 2013: 7).
Dari perkataan tersebut dapat disimpulkan bagaimana Margreth berusaha menanamkan nilai keagamaan pada diri Friedrich. Dalam suasana gelisah karena suaminya tidak pulang-pulang, Margreth berusaha mengajak Freiderich untuk berdoa. Margreth mengatakan bahwa Tuhan selalu menjaga mereka dalam setiap kesulitan.

Religiusitas yang ditanamkan ibunya Margreth ternyata tidak berpengaruh terhadap kepribadian Friedrich. Dengan demikian, seleksi alam yang terjadi pada diri Friedrich menunjukkan bahwa perilaku yang kurang menguatkan berupa perilaku keagamaan pada diri Friedrich kemudian dihilangkan. Pengaruh keagamaan yang ditanamkan oleh ibunya semasa Friedrich masih kecil ternyata tidak membekas pada dirinya, bahkan kemudian menghilang secara berangsur-angsur dengan beranjaknya Friedrich menuju kedewasaan.

Kontrol sosial belum begitu nampak pada masa ketika Friedrich masih kecil. Lingkungan belum begitu memberi pengaruh terhadapnya dengan memberi penguatan (reward) ataupun hukuman (punisment). Hal ini disebabkan Friedrich belum menampakkan perilakunya secara keseluruhan. Dalam NovelleDie Judenbuche ini, masa kecil Friedrich tidak dibicarakan secara lebih mendalam. Masa kecil Friedrich berkaitan dengan ayahnya yang sangat menyayanginya dan selalu memberinya hadiah ketika pulang.

\section{Saat Kematian Ayahnya}

Perkembangan kepribadian Friedrich di saat dia kehilangan ayahnya digambarkan sangat berbeda dengan masa kecilnya. Perkembangan kepribadian Friedrich sangat dipengaruhi oleh peristiwa kematian ayahnya. Kematian ayahnya yang bagi dirinya sangat mengagetkan, menjadi sangat mengganggu perkembangan jiwanya. Hal ini diperkuat cerita-cerita tentang ayahnya yang didengar dari orang lain. Hal tersebut membuat Friedrich menjadi sangat perasa.

Dalam hal ini, seleksi alam tidak begitu muncul dan mempengaruhi kepribadiannya. Kontrol sosial justru kelihatan dominan dalam mempengaruhi kepribadiannya. Kontrol sosial sudah dimulai sejak peristiwa ayahnya meninggal. Kontrol sosial pada diri Friedrich tersebut 
berpengaruh terhadap proses seleksi alam, karena perilaku Friedrich yang memang tidak menguatkan karena kontrol dari orang lain tersebut akhirnya berhenti dan tidak diteruskan.

Friedrich berusaha melakukan strategi perlawanan terhadap kontrol sosial tersebut dengan cara memberontak, tetapi karena dia masih kecil, usaha itu tidak membawa hasil. Sebagai contoh, ketika masyarakat melakukan kontrol sosial dengan cerita-cerita tantang ayahnya yang telah menjadi hantu di hutan Brederholz, dia akan berteriak keras, memukul dan bahkan melukai dirinya sendiri.Pemberontakan Friedrich dilakukan ketika masyarakat sering menceritakan tentang ayahnya yang katanya jadi hantu di hutan Brederholz. Mendengar cerita tersebut Friedrich sering memberontak dengan cara berteriak keras, menelungkupkan dirinya, dan kadang melukai dirinya dengan pisau. ("Friedrich mußte von andern Knaben vieles darüber hören; dann heulte er, schlug um sich, stach auch einmal mit seinem Messerchen und wurde bei dieser Gelegenheit jämmerlich geprügelt”) (Hullshof, 2013: 34). Akhir pemberontakan itu ditunjukkan dengan menghindari interaksi dengan warga desa B lainnya dan memilih menyendiri pada waktu menggembala sapinya. Kontrol sosial dari masyarakat desa B tersebut telah membuat perkembangan kepribadian Friedrich terganggu sehingga dia menjadi anak yang pendiam dan pemalu.

\section{Saat Friedrich Diadopsi Simon Semmler}

Sejak berada di bawah pengasuhan pamannya, Friedrich meninggalkan perilaku keagamaan seperti yang diajarkan dan dicontohkan ibunya kepadanya. Proses seleksi alam dengan sendirinya terjadi dalam hal ini. Perkembangan kepribadiannya berkembang secara pesat. Friedrich yang tadinya pemalu dan pendiam, sekarang berkembang menjadi pemuda yang pemberani. Dia juga selalu berpenampilan baik sehingga ketampanannya segera terkenal di kalangan pemuda di desa tersebut. Hal tersebut terjadi karena kontrol sosial yang dilakukan oleh pamannya. Pamannya Simon memberi penguatan positif kepadanya berupa reward dengan banyak memberi kepercayaan kepadanya.
Keberanian Friedrich semakin dikenal saat Friedrich berusia 18 tahun. Friedrich dinyatakan menang dalam sebuah pertaruhan memanggul babi jantan sepanjang dua mil di atas punggungnya tanpa menurunkannya.

"In seinem achtzehnten Jahre hatte Friedrich sich bereits einen bedeutenden Ruf in der jungen Dorfwelt gesichert durch den Ausgang einer Wette, infolge deren er einen erlegten Eber über zwei Meilen weit auf seinem Rücken trug, ohne abzusetzen." (Hullshof, 2013: 16)

Pengakuan dari masyarakat diberikan kepada Friedrich atas keberaniannya tersebut. Dengan demikian, kontrol sosial diberikan masyarakat berupa penguatan positif atas kehebatannya.

Friedrich kemudian menunjukkan perilaku yang lebih menunjukkan keberaniannya lagi. Dia berusaha dengan segala cara untuk mendapatkan uang, karena dia membutuhkannya untuk memenuhi kebutuhan penampilannya. Friedrich selalu berusaha untuk tidakketinggalan mengikuti mode pakaian yang sedang trend di kalangan pemuda di desa B saat itu walaupun sebenarnya hal itu sulit. Untuk itu dia mengerahkan segenap kekuatannya, dan selalu menyibukkan diri dalam setiap kegiatan dan berupaya keras untuk mendapatkan ketenaran.

Karena pengakuan yang diberikan masyarakat atas keberaniannya dan juga penampilannya, Friedrich berusaha dengan segala cara untuk selalu mendapatkan pengakuan dari masyarakat dalam berbagai hal. Pengakuan dari masyarakat adalah kontrol sosial yang berupa penguatan positif. Pengakuan merupakan reward atas keberanian dan penampilan yang ditunjukkan oleh Friedrich. Penguatan positif yang diberikan oleh masyarakat membuat Friedrich semakin yakin bahwa dia akan diakui oleh masyarakat kalau dia menunjukkan kehebatannya dan menunjukkan cara berpenampilan yang baik.

\section{Ketika Friedrich Terlibat atas Kematian Brandis}

Friedrich mengalami perkembangan kepribadian yang pesat setelah berada di bawah 
pengasuhan pamannya Simon. Karena penguatan positif yang diberikan oleh masyarakat, maka keberanian Friedrich semakin tumbuh, termasuk keberaniannya untuk berbuat jahat. Karena dia selalu membutuhkan uang yang banyak untuk memelihara penampilannya, maka dia tidak segan-segan melakukan tindakan yang salah. Dalam hal ini, seleksi alam berperan penting. Tindakan Friedrich yang cenderung menguatkan dirinya, kemudian diulangi lagi secara terus menerus.

Keterlibatan Friedrich dengan kelompok pencuri Blaukitteln tidak dapat dibuktikan dengan jelas sehingga perilaku Friedrich yang salah tersebut bisa dilakukan terus menerus. Kontrol masyarakat belum berlaku di sini, karena tidak ada bukti yang nyata, meskipun masyarakat sebenarnya mencurigai bahwa di antara kelompok pencuri katu itu pasti ada mata-mata dari kalangan desa $\mathrm{B}$ sendiri. Karena tidak adanya kontrol dari masyarakat, perilaku jahat Friedrich tetap dilakukan secara terus menerus.

Bahkan akhirnya, perilaku jahat Friedrich semakin berkembang tanpa kontrol. Hanya karena tersinggung oleh perkataan Brandis yang mengejek hidupnya yang miskin, Friedrich telah membuat Brandis dibunuh oleh kelompok pencuri katu tersebut. Friedrich telah mengarahkan Brandis kepada kematiannya, karena dia menunjukkan jalan yang salah ketika Brandis menanyakan jalan menuju teman-teman penjaga hutan yang lain. Seharusnya Brandis menuju ke Mastergrund untuk bisa menemukan temanteman penjaga hutan yang lain. Akan tetapi, Friedrich telah menunjukkan arah ke pohon Buche, di mana kelompok Blaukittel berada. Akhirnya Brandis dibunuh oleh kelompok pencuri itu karena niat jahat Friedrich.

Kontrol sosial sebenarnya dilakukan masyarakat karena masyarakat curiga bahwa Friedrichlah yang telah membuat Brandis terbunuh. Karena Friedrich juga melakukan strategi perlawanan dengan menciptakan alibi yang bisa diterima tetapi tidak ada bukti yang kuat, akhirnya kontrol tersebut lepas dengan sendirinya. Dengan demikian, penguatan positiflah yang terjadi pada diri Friedrich. Tidak ada punishment terhadap kejahatan yang dilakukan oleh Friedrich terhadap Brandis. Sangsi tidak bisa diberikan karena tidak ada bukti yang menunjukkan bahwa Friedrich telah bersalah.

Karena tidak adanya punishment, Friedrich semakin berkembang menjadi pribadi yang tidak baik. Berbagai sifat jelek melekat pada dirinya. Masyarakat mengenal karakternya yang sombong, cepat tersinggung, kelihatan polos namun sebenarnya licik, dan sebagainya. Seleksi alam terhadap perilaku Friedirch menunjukkan bahwa perilaku Friedrich yang menguatkan dirinya cenderung akan diulangi. Perilaku Friedrich yang jelek, kemudian terus menerus diulangi, apalagi kontrol dari masyarakat juga cenderung lemah. Tidak ada sangsi berupa punisment yang diberikan secara tegas oleh masyarakat kepada Friedrich. Hal tersebut membuat kepribadian Friedrich yang terbentuk dari perilaku yang dilakukan setiap harinya menunjukkan kecenderungan yang semakin memburuk.

\section{Saat Pembunuhan terhadap Aaron}

Friedrich terus mengalami perkembangan kepribadian sebelum dan sesudah pembunuhan yang dilakukan terhadap Tuan Aaron. Tidak adanya sangsi pada saat dia terlibat pada pembunuhan Tuan Brandis membuat Friedrich semakin berani. Hanya karena masalah sepele dengan seseorang, dengan mudah Friedrich akan berusaha melawan orang tersebut. Bahkan lebih kejam lagi, dia berusaha menghilangkan nyawa orang tersebut. Seleksi alam terjadi pada diri Friedrich, perilaku yang menguatkan bagi Friedrich dan juga tidak adanya kontrol sosial berupa hukuman padanya, membuat Friedrich semakin nekat.

Kekejamannya bertambah dengan membunuh langsung Tuan Aaron, sementara pada Brandis dia membunuhnya dengan menggunakan tangan orang lain, yakni kelompok pencuri Blaukitteln. Dengan demikian, Friedrich mengalami perkembangan kepribadian yang semakin signifikan. Perkembangan kepribadian Friedrich semakin mengarah kepada kejahatan. Kecenderungannya untuk berbuat jahat semakin meningkat. Keberanian Friedrich disertai dengan kesombongannya, membuatnya mudah berbuat nekat, jika dia merasa harga dirinya terlukai. Ketika dia merasa dipermalukan di depan orang banyak oleh Tuan Aaron, niat jahat 
Friedrich langsung muncul. Akan tetapi, kejahatan itu tidak langsung dilakukan melainkan menunggu sampai tiga hari. Tiga hari berikutnya orang menemukan mayat Aaron meninggal di hutan Brederholz.

Seperti yang terjadi pada peristiwa pembunuhan terhadap penjaga hutan Brandis, Friedrich juga langsung dicurigai sebagai orang yang membunuh Tuan Aaron. Tuan S langsung mengadakan pemeriksaan dan berusaha menangkap Friedrich. Karena Friedrich sudah melarikan diri, maka pemeriksaan terhenti. Dengan demikian, kontrol masyarakat berupa penegakan hukum terhadap pelaku pembunuhan tidak bisa ditegakkan di desa B tersebut. Friedrich bisa terlepas dari sangsi yang harusnya diterimanya.

Usaha Friedrich melarikan diri merupakan strategi dirinya dalam menghindari kontrol sosial pada dirinya. Friedrich sebenarnya merasa takut untuk menghadapi kontrol sosial dari masyarakat terhadapnya. Meskipun Friedrich adalah orang yang berani dan selalu menunjukkan kekuatannya, tetapi ternyata pribadinya tidak kuat. Setelah membunuh Tuan Aaron, Friedrich merasa ketakutan terhadap sangsi yang akan diberikan kepadanya. Dia tidak siap untuk menerima sangsi tersebut. Oleh karena itu, dia memutuskan untuk melarikan diri bersama sahabatnya Johannes Niemand. Seperti dulu setelah menunjukkan arah yang salah kepada Brandis dan menyebabkan kematian Brandis, Friedrich merasa menyesal sehingga dia ingin melakukan pengakuan dosa. Dengan demikian, sebenarnya hati nurani Friedrich masih berbicara. Karena dihalangi oleh pamannya Simon, dia tidak jadi ke gereja untuk mengaku dosa. Begitu juga setelah membunuh Tuan Aaron, hati nurani Friedrich sebenarnya juga menyesal. Oleh karena itu, dia kemudian memutuskan untuk melarikan diri.

\section{Saat Friedrich Kembali dan Bunuh diri}

Kepulangan Friedrich setelah selama dua delapan tahun pergi meninggalkan tanah airnya merupakan bentuk keterikatan Friedrich dengan tanah kelahirannya. Meskipun dia bisa mendapatkan kehidupan yang lebih baik pada saat pelariannya, tetapi Friedrich lebih memilih jalan untuk pulang mendekati tanah kelahirannya.
Dalam diri Friedrich, ada semacam keterikatan yang mengikat setiap langkahnya ketika dia melarikan diri dari tanah airnya. Ketika ditanya oleh Tuan S, Friedrich menjawab bahwa langkahnya selalu membawanya pulang ke tanah airnya. Padahal ketika dia tiba dengan kapal di Amsterdam, dia ditawari oleh pemilik kapal pekerjaan menjadi penjaga pintu. Friedrich lebih memilih untuk mengemis dan akhirnya kakinya mengarahkannya kembali ke tanah airnya.

Friedrich yang sudah pergi jauh meninggalkan desa dan tanah airnya, setelah 28 tahun tetap tergerak untuk kembali ke daerahnya. Meskipun dia menutupi identitas dirinya dengan identitas Johannes, tetapitakdir tetap menuntunnya untuk mendekati pohon Buche tersebut sehingga mantra yang dibuat oleh warga Yahudi tersebut akhirnya mengenainya.Friedrich menggantungkan dirinya di pohon Buche tersebut hingga menemui ajalnya. Tulisan dalam bahasa Ibrani yang berbunyi "Jika kamu mendekat pada tempat ini, maka akan terjadi, apa yang kamu lakukan dulu dulu kepadaku".

\section{אם העמוד במקום חוח יפגע בך כאשר אחה עמית לי}

("Wenn du dich diesem Orte nahest, so wird es dir ergehen, wie du mir getan hast) (Hullshof, 2013: 34).Tulisan yang digantungkan oleh orang Yahudi, yang berisi mantratersebut akhirnya terwujud. Friedrich ternyata memang pelaku pembunuhan terhadap Tuan Aaron, sehingga ketika dia mendekati pohon tersebut, akhirnya terjadi juga apa yang dulu dilakukan oleh Friedrich terhadap Tuan Aaron. Dia mati menggantungkan diri pada pohon tersebut.

Dengan demikian, perjalanan hidup Friedrich dihentikan oleh kontrol sosial dari masyarakat, yakni dari warga Yahudi setelah Friedrich masih bisa terlepas dari kontrol sosial masyarakat dari desa B. Setelah terlepas dari kontrol sosial masyarakat karena kejahatannya, akhirnya Friedrich tidak bisa lepas dari hukuman masyarakat Yahudi. Hukuman itu disimbolkan dengan keberadaan pohon Buche yang berada di hutan Brederholz, sehingga pohon tersebut kemudian diberi nama Judenbuche atau pohon Buche milik orang Yahudi. 


\section{Pengaruh Lingkungan terhadap Perkem- bangan Kepribadian Tokoh Utama Friedrich Mergel}

Lingkungan memang sangat berpengaruh dalam pembentukan kepribadian Friedrich. Lingkungan yang secara garis besar diwakili oleh tiga hal, yakni seleksi alam, kontrol sosial dan penguatan memberi pengaruh besar bagi kepribadian Friedrich.

Dalam seleksi alam, beberapa perilaku Friedrich yang menguatkan dan secara positif bermanfaat bagi keberadaan dirinya, terus dilakukan secara berulang. Dalam hal ini yang berkembang pada diri Friedrich adalah perilaku Friedrich yang mengarah kepada kejahatan. Perilaku yang berkaitan dengan nilai-nilai keagamaan yang seharusnya menguatkan dan bermanfaat secara positif akhirnya diabaikan dan lama-lama dihilangkan. Hal tersebut disebabkan nilai-nilai tersebut tidak mempengaruhi keberlangsungan diri Friedrich sehingga nilai tersebut mulai meluntur dan akhirnya hilang.

Perkembangan kepribadian Friedrich juga dipengaruhi oleh kontrol sosial. Dalam hal kontrol sosial, perilaku Friedrich dari kecil sebenarnya sudah dikontrol oleh masyarakat. Hampir dalam semua fase kehidupan Friedrich, kontrol masyarakat terhadap perilaku Friedrich sudah dilakukan. Akan tetapi, kontrol sosial yang tidak terlalu kuat dan bahkan permisif membuat kepribadian Friedrich semakin sulit dikontrol, apalagi dalam menghadapi kontrol sosial tersebut, Freidrich juga melakukan strategi perlawanan.

Salah satu strategi menghadapi kontrol masyarakat adalah ketika Friedrich terlibat dalam pembunuhan terhadap Penjaga Hutan Brandis yang dilakukan dengan cara menghindar. Dia berusaha menghindari kontrol sosial dari masyarakat ketika dia dituduh ikut terlibat dalam pembunuhan tersebut. Usahanya menghindar dimulai ketika dia berusaha menciptakan alibi bahwa dia sudah pulang ke rumah ketika peristiwa pembunuhanBrandis terjadi, sekitar tigaperempat jam setelahnya. Dia juga pulang dalam keadaan sakit sehingga tidak mungkin keluar rumah lagi dan terlibat dalam pembunuhan tersebut.

"Sein Alibi zur Zeit des Mordes war leicht erwiesen. Der Förster lag am Aus- gange des Masterholzes; über dreiviertel Stunden Weges von der Schlucht, in der er Friedrich um vier Uhr angeredet und aus der dieser seine Herde schon zehn Minuten später ins Dorf getrieben." (Hullshoff, 2013: 10).

Alibinya bisa diterima sehingga lambat laun tuduhan bahwa dirinya terlibat dalam pembunuhan tersebut menghilang.

Terlepas dari kontrol masyarakat ketika dia terlibat dalam pembunuhan terhadap Brandis, membuat Fredrich semakin berani dan bahkan cenderung lebih nekat. Hanya karena tersinggung karena dipermalukan di depan umum, Friedrich berkembang kejahatanya dengan membunuh Tuan Aaron. Kontrol sosial masyarakat langsung ditujukan kepada Friedrich karena semua orang yakin bahwa dialah yang membunuh Tuan Aaron. Friedrich menunjukkan strateginya dengan cara menghindar. Dia melarikan diri dari desa B sebelum masyarakat memberikan hukuman kepadanya. Ketika Tuan S mencarinya ke rumahnya, Tuan S tidak menemukannya, hanya tempat tidurnya yang masih hangat. Ketika dicari di tempat lain, Friedrich tetap tidak ditemukan karena dia sudah melarikan diri.

"Man trat in Friedrichs Kammer. Er war nicht da, aber das Bett noch warm. Man stieg auf den Söller, in den Keller, stieß ins Stroh, schaute hinter jedes Faß, sogar in den Backofen; er war nicht da. Einige gingen in den Garten, sahen hinter den Zaun und in die Apfelbäume hinauf; er war nicht zu finden". (Hullshoff, 2013: 31).

Friedrich sudah melarikan diri jauh. Polisi pun tidak mungkin menemukannya. Pelariannya berhasil sehingga hukuman yang harusnya diterima olehnya bisa dihindarinya. Bahkan, warga masyarakat pun lambat laun melupakannya. Dia sudah hilang tanpa bekas dan akhirnya dilupakan. "Er war bald verschollen, vergessen”. (Hullshoff, 2013: 34). Dengan demikian, strategi Friedrich untuk menghindari kontrol sosial dari masyarakat desa B telah berhasil. 
Karena keberhasilannya melawan kontrol soaial, kepribadiannya semakin berkembang semakin negatif. Akan tetapi, pada akhirnya Friedrich tidak mampu lagi mengelak dari kontrol sosial yang berupa hukuman dari warga Yahudi, ketika Friedrich tidak mampu lagi menghindari mantra yang digantungkan di pohon Buche tersebut. Strateginya untuk menghindar tidak lagi berhasil, sehingga perkembangan kepribadiannya akhirnya berhenti dengan ditemukannya meninggal di pohon Buche tersebut.

\section{PENUTUP}

Perkembangan kepribadian Friedrich dipengaruhi oleh tiga hal yaitu seleksi alam, praktik budaya berupa kontrol sosial, dan sejarah seseorang atas penguatan (reinforcement) yang diterima. Ketiga hal tersebut secara garis besar dikatakan sebagai lingkungan yang mempengaruhi kepribadian manusia.

Perkembangan kepribadian Friedrich terbagi dalam beberapa fase kehidupan Friedrich, yakni pada saat Friedrich kecil, saat kematian ayahnya, saat Friedrich diadopsi Simon Semmler, ketika terlibat atas kematian Brandis, saat pembunuhan terhadap Aaron, serta saat Friedrich kembali dan bunuh diri. Dalam keenam fase tersebut, ketiga faktor yang membentuk kepribadian seseorang, yakni seleksi alam, praktik budaya berupa kontrol sosial dan penguatan (reinforcement) pada diri Friedrich, saling memberikan pengaruh dan berkaitan satu sama lain.

\section{DAFTAR PUSTAKA}

Feist, Jess. 2011. Teori Kepribadian. Jakarta: Salemba Humanika.

Ratna, Nyoman Kutha. 2004. Teori, Metode, dan Teknik Penelitian Sastra. Yogyakarta: Pustaka Pelajar.

Sujanto, Agus dkk. 2001. Psikologi Kepribadian. Jakarta: PT. Bumi Aksara.

Hullshoff, Annete von Dröste. 2013. Die Judenbuche. Hamburg: Hamburger Lesehefte Verlag.

Wiyatmi, 2001. Psikologi Sastra. Yogyakarta: Kanwa Publisher. 